\title{
Dynamics of the phytoplankton community of an Argentine Pampean wetland in relation to water environmental variables
}

\section{Dinámica de la comunidad fitoplanctónica de un humedal pampeano argentino en relación con variables ambientales del agua}

\author{
Noelia Leonor Cony, Nora Cristina Ferrer and Eduardo Jorge Cáceres
}

Departamento de Biología, Bioquímica y Farmacia, Universidad Nacional del Sur, San Juan 670, Bahía Blanca, 8000, Argentina e-mail: noeliacony@gmail.com

Recibido: 15 de diciembre de 2015. Aceptado: 18 de enero de 2017.

Cony N. L., N. C. Ferrer and E. J. Cáceres. 2017. Dynamics of the phytoplankton community of an Argentine Pampean wetland in relation to water environmental variables. Hidrobiológica 27 (1): 93-102. D0l: 10.24275/uam/izt/dcbs/hidro/2017v27n1/Cony

\begin{abstract}
Background. Shallow lakes are an essential component of the Argentine Pampean wetlands. The Sauce Grande shallow lake is a typical water body of the Argentine Pampean wetlands, based on its shallow characteristics and its homogeneity in terms of physical, chemical, and biological characteristics. Phytoplankton is dominant in the turbid shallow lake and is sensitive to internal fluctuations in the water body and prevailing environmental conditions that affect its abundance and distribution. Goals. We conducted a temporal and spatial analysis of the distribution and abundance of the phytoplankton community in the Sauce Grande shallow lake (province of Buenos Aires, Argentina), from April to September 2012, in order to study the influence of physicochemical variables of the water on phytoplankton. Methods. We undertook Cluster Analysis (CA), Principal Component Analyses (PCA) and Spearman correlations between the biotic and physicochemical variables recorded at two sites of the shallow lake. Results. The multivariate analysis showed that certain water physicochemical factors (conductivity, depth, pH, turbidity, and temperature) profoundly influenced the phytoplankton dynamics, giving rise to a seasonal succession of community species, with a clear dominance of Cyanobacteria. The Spearman correlation showed that Cyanobacteria relate positively and significantly to conductivity whereas Chlorophyta and Bacillariophyta relate negatively and significantly to temperature, $\mathrm{pH}$, conductivity, and salinity. Chlorophyta was the group with the highest number of recorded taxa while Cyanobacteria constituted the largest group, the most abundant species being Synechocystis salina Wislouch. Conclusions. The results obtained in this study demonstrate that the phytoplankton community of the Sauce Grande shallow lake is highly susceptible to changes in water environmental conditions, in particular to water level fluctuations, and to conductivity, $\mathrm{pH}$, and temperature.
\end{abstract}

Key words: Cyanobacteria, multivariate analysis, phytoplankton community, Sauce Grande shallow lake, Synechocystis salina.

\section{RESUMEN}

Antecedentes. Las lagunas son el componente esencial del humedal pampeano argentino. La laguna Sauce Grande es un típico cuerpo de agua pampeano en base a sus características someras y su homogeneidad en las características físicas, químicas y biológicas. El fitoplancton se muestra dominante en las lagunas turbias, y es sensible a las fluctuaciones internas del cuerpo de agua y a las condiciones ambientales prevalecientes, viéndose afectadas su abundancia y distribución. Objetivos. Se realizó un análisis temporal y espacial de la comunidad fitoplanctónica de la laguna Sauce Grande (Provincia de Buenos Aires, Argentina), durante el período abril-septiembre de 2012, y se estudió la influencia de las variables fisicoquímicas del agua sobre la comunidad fitoplanctónica. Métodos. Se realizaron análisis de Cluster (CA), análisis de componentes principales (ACP) y correlaciones de Spearman entre las variables bióticas y fisicoquímicas registradas en dos sitios de la laguna. Resultados. El análisis multivariado mostró la influencia de la conductividad, salinidad, profundidad, pH y temperatura en la dinámica del fitoplancton, resultando en una sucesión estacional de especies de la comunidad, con una clara dominancia de cianobacterias. Las correlaciones de Spearman demostraron que la densidad de cianobacterias se relacionó positiva y significativamente con la conductividad, mientras que las abundancias de Chlorophyta y Bacillariophyta se relacionaron negativa y significativamente con la temperatura, $\mathrm{pH}$, conductividad y salinidad. Chlorophyta fue el grupo con el mayor número de taxones registrados, mientras que Cyanobacteria constituyó el grupo más abundante, siendo Synechocystis salina Wislouch la especie más abundante. Conclusiones. Los resultados obtenidos en esta investigación demostraron la alta susceptibilidad de la comunidad fitoplanctónica de la laguna Sauce Grande a los cambios en las variables ambientales, en particular, a las fluctuaciones en el nivel del agua y luego, a la conductividad, pH y temperatura.

Palabras clave: Análisis multivarido, comunidad fitoplanctónica, Cyanobacteria, Laguna Sauce Grande, Synechocystis salina. 


\section{INTRODUCTION}

Shallow lakes are an essential component of the Argentine Pampean wetlands, one of the most extensive wetland areas in South America. Lakes on the plain are shallow with brief periods of thermal stratification (Quirós, 2005). Shallow lakes often alternate between two states: a turbid one, in which phytoplankton dominates productivity; and a relatively clearer vegetated state, in which rooted vegetation dominates productivity (Scheffer et al., 1993; Scheffer et al., 2003). There is a third state of shallow lakes found in the Argentine Pampean wetlands, which also corresponds to turbid lakes, in which turbidity is mostly due to suspended inorganic material (Torremorell et al., 2007). Bilotta \& Brazier (2008) defined turbidity as a measure of the light scattering properties of water, and their readings were influenced by the particle size and shape of suspended solids, the presence of phytoplankton, and the presence of dissolved matter and mineral substances. These systems normally show a high sequential phytoplankton population variability with frequent changes in the composition and relative abundance of species as a result of the interactions between the physical, chemical, and biological variables (Calijuri et al., 2002) that have a notable influence on the structure of the phytoplankton community (Rojo et al., 2000; Phlips et al., 2002). The Sauce Grande shallow lake is a typical shallow Pampean lake (Ringuelet, 1972), given its shallow nature and the homogeneity of its physicochemical and biological parameters. This homogeneity is frequently affected by both extreme drought and intense rainfall, which produce drastic changes within its structure and performance (Quirós et al., 2002 a, b). Shallow lakes, which are globally the most common and widespread inland water bodies (Downing et al., 2006), are particularly vulnerable to drought and unbalanced ratios between evaporation and precipitation (Jeppesen et al., 2009; Moss et al., 2011) due to their large surface:volume ratio (Coops et al., 2003). In this sense, Izaguirre et al. (2015) demonstrated the vulnerability of most Pampean shallow lakes to water level fluctuations. Moreover, the structure and dynamics of the phytoplankton community may be susceptible to climatic changes that alter the level of the lake water through evaporation and changes in the flow of the stream network in the water supply basin (Coops et al., 2003).

The Sauce Grande shallow lake was recently characterized as a murky water body dominated by phytoplankton (Ferrer et al., 2012). In the fall of 2010 it was found to be in a eutrophic condition based on measurements of chlorophyll a and water transparency (Ferrer et al., 2012) and even hypertrophy was recorded during 2012-2013 (Cony et al., 2014).

Although there are studies of the lake's phytoplankton (Ferrer et al., 2012; Cony et al., 2014), none of them has dealt with the relationships between biotic and abiotic variables. The aim of this investigation was to analyze the temporal and spatial distribution of abundance in the phytoplankton community of the Sauce Grande shallow lake relating these factors to the physicochemical variables of the water body. The study was carried out under the premise that phytoplankton populations are sensitive to internal physicochemical fluctuations of the water body and to prevailing environmental conditions that affect their abundance and distribution. We suggest that a better comprehension of phytoplankton dynamics in this shallow lake will be achieved by the correlation with physicochemical variables. In this paper, we intend to identify the variables that are most influential on the phytoplankton community, in particular temperature, turbidity, $\mathrm{pH}$, electric conductivity, and salinity.
Knowledge of the Sauce Grande shallow lake phytoplankton dynamics will be an important tool for a better understanding of shallow water systems in the Pampean wetlands.

\section{MATERIALS AND METHODS}

The Sauce Grande shallow lake is located in southwestern Buenos Aires Province, Argentina ( $38^{\circ} 57$ 'S-61 $24^{\circ}$ ' W). This system has an area of $21.55 \mathrm{~km}^{2}$ and depths ranging between $0.60 \mathrm{~m}$ and $1.80 \mathrm{~m}$, with a historical average depth of $1.40 \mathrm{~m}$ (Fornerón et al., 2010a). The Sauce Grande River feeds the shallow lake from the west and drains it to the east before flowing into the sea (Fig. 1). The region is temperate and humid with mean annual temperatures between $14{ }^{\circ} \mathrm{C}$ and $20^{\circ} \mathrm{C}$ (Ferrer et al., 2012). Rainfall is irregular, ranging between $600-700 \mathrm{~mm}$ annually. The Sauce Grande shallow lake has an interesting regional importance because of the numerous recreational activities that take place there throughout the year.

Monthly samples were collected from April to September 2012 at two easily-accessible sites: S1, representative of the littoral sector of the lagoon near the exit of the Sauce Grande River, and S2, in the recreational sector (Fig. 1). The water body was extremely shallow during the study period, preventing access by any type of boat. Water environmental variables were recorded in situ: temperature $\left({ }^{\circ} \mathrm{C}\right)$, turbidity (NTU), pH, electric conductivity (EC, $\mathrm{mS}_{\mathrm{cm}}{ }^{-1}$ ), and salinity (PSU), with a Horiba U-10 multisensor. In addition, transparency was estimated using a Secchi disk.

Qualitative samples, subsurface mode, were taken with a plankton net of $30 \mu \mathrm{m}$ mesh aperture, one from each sampling site, and were fixed, in situ, with $4 \%$ formaldehyde. Observations were made with two microscopes, a Leitz SM Lux and a Zeiss Axiolab. We identified the samples with specialized literature for the dominant algal groups (Bourrely, 1966; Hindák, 1977, 1984, 1988, 1990; Komárek \& Anagnostidis, 1999, 2005; Komárek \& Fott, 1983) and with similar studies conducted in the Pampean wetlands (Guarrera et al., 1968, 1972).

Quantitative analyses were performed on samples taken sub-superficially with plastic bottles and fixed in situ with Lugol's solution. Counts were made under a Nikon Eclipse TE 300 inverted microscope with Nikon Digital Sight DS-U2 incorporated, with a Sedgwick-Rafter camera, according to the method of McAlice (1971). Abundance was expressed as the number of individuals per milliliter (ind. $\mathrm{ml}^{-1}$ ).

In order to analyze the similarity between sampled sites and months, a cluster analysis was performed based on a complete linkage of the physicochemical and environmental variables (conductivity, depth, $\mathrm{pH}$, temperature, salinity, and turbidity.) In addition, a Spearman correlation was performed between these physicochemical variables and the abundance of the represented taxonomic groups.

Moreover, two principal component analyses (PCA-1 and PCA-2) were performed, to locate and relate the biological and physicochemical variables in space. PCA-1 was based on the abundance of represented taxonomic groups together with physicochemical variables for each site, whereas in PCA-2 the phytoplankton specific abundances were related to the occurrence frequencies (F0) $\geq 70 \%$. In all cases, logarithmic transformed data were used. The "Infostat Student Version" software was used for the analyses. 


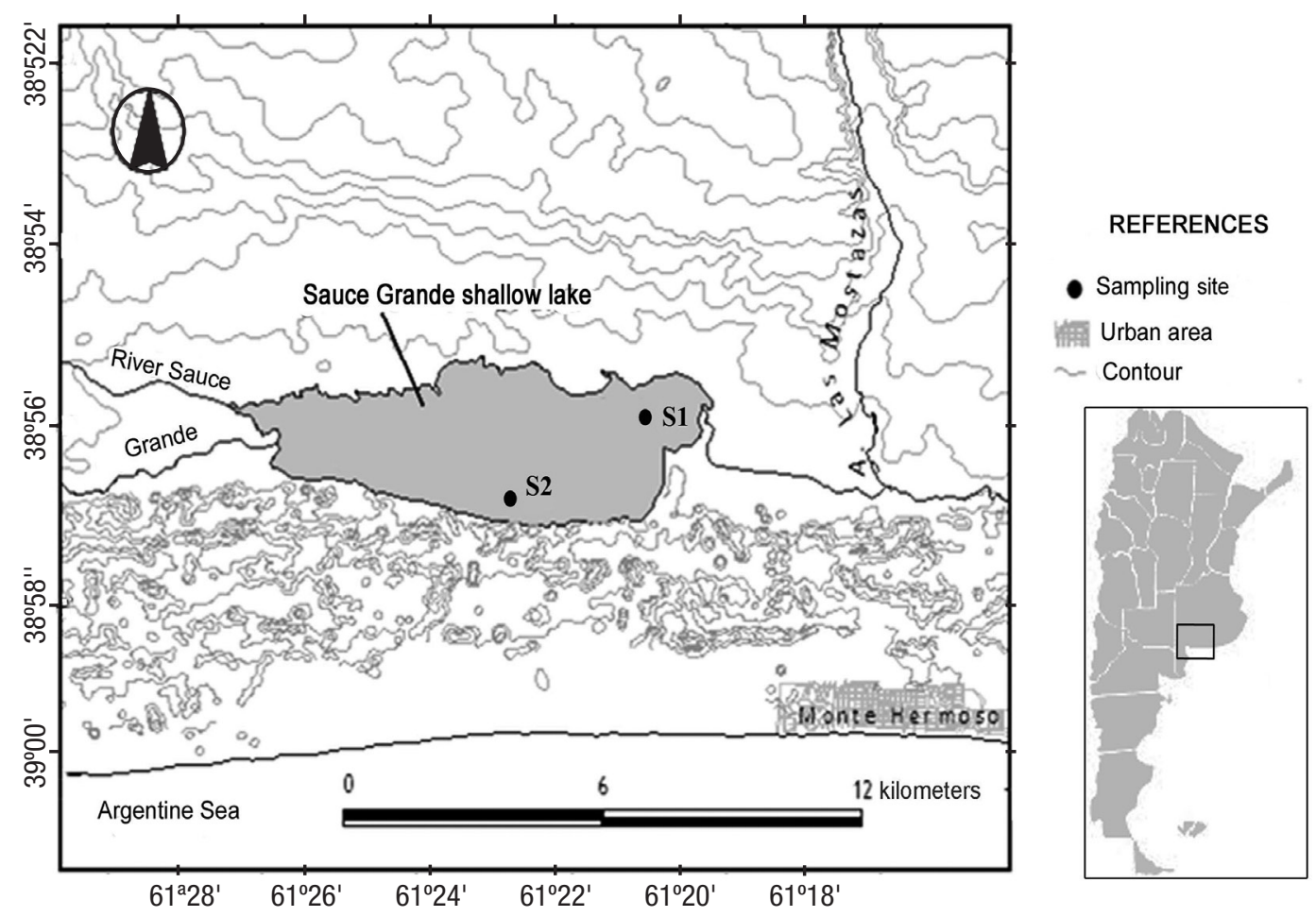

Figure 1. Location of the Sauce Grande shallow lake (Argentine Pampean wetland) and sampling sites (S1 and S2).

\section{RESULTS}

Physicochemical factors. Table 1 shows the values of the environmental variables recorded at the sampling sites. Mean $\mathrm{pH}$ values were 10.1 and 10.4 at sites 1 and 2 respectively, conductivity rose from 6.3 to $10.1 \mathrm{mS} \mathrm{cm}^{-1}$, and the minimum was recorded at site 2 and the maximum at site 1 (Fig. 2). Salinity averaged 0.5 PSU at both sites. Turbidity was high throughout the entire study period, with saturation values of 999 NTU at both sites.

Depths recorded in August 2012 were very low at both sites, the minimum being $0.10 \mathrm{~m}$ for site 2 and the maximum $0.5 \mathrm{~m}$ for site 1 .

Phytoplankton qualitative analysis. The phytoplankton composition was similar for both groups and species at both sampling sites. Of 54 taxa identified, 30 were Chlorophyta (55.5\%), 14 belonged to Cyanobacteria (26\%), and 10 to Bacillariophyta (18.5\%). From the latter, seven $(70 \%)$ were pennate and three $(30 \%)$ centric (Fig. 3). Table 2 shows the species identified at both sites: Dictyosphaerium ehrembergianum Näegeli and Oocystella borgei (J.Snow) Hindák were only found in August 2012 at site 2; Oocystis eremosphaeria G.M. Smith appeared in May, July, and August only at site 2; Pediastrum boryanum (Turp.) Meneghini in August at site 2 and Planctonema lauterbornii Schmidle were only found in May 2012 at both sites; Staurastrum planctonicum (Teiling), Tetraedron caudatum (Corda) Hansgirg, and $T$. minimun (A. Braun) Hansgirg were only identified at site 1. Meanwhile, the Cyanobacteria Aphanotece clathrata (West et G.S.West) was found in September 2012, only at site 1. Among diatoms, Chaetoceros mueIleri Lemmermann only appeared in April 2012 at site 2, Navicula aff. gregaria Donkin was found at site 1 in April, August, and September; Pseudostaurosira brevistriata var. inflata (Pantocsek) Hartley only in July and September, and Surirella striatula Turpin in August 2012, at both sites 1 and 2 .

Table 1. Minimum, maximum, average ( $\overline{\mathrm{x}})$, and standard deviation (SD) of the physicochemical variables recorded during April-September 2012 in an Argentine Pampean wetland. Values: NTU: Natural Turbidity Units; PSU: Practical Salinity Units.

\begin{tabular}{|c|c|c|c|c|c|c|c|c|}
\hline \multirow[b]{2}{*}{ Variable } & \multicolumn{4}{|c|}{ Site 1} & \multicolumn{4}{|c|}{ Site 2} \\
\hline & Min & Max & $\bar{x}$ & SD & Min & Max & $\bar{x}$ & SD \\
\hline Conductivity $\left(\mathrm{mS} . \mathrm{cm}^{-1}\right)$ & 9.1 & 10.1 & 9.7 & 0.3 & 6.3 & 9.7 & 8.7 & 1.6 \\
\hline $\mathrm{pH}$ & 9.9 & 10.3 & 10.1 & 0.1 & 10.1 & 10.5 & 10.4 & 0.2 \\
\hline Turbidity (NTU) & 999.0 & 999.0 & 999.0 & 0.0 & 999.0 & 999.0 & 999.0 & 0.0 \\
\hline Depth (m) & 0.3 & 0.5 & 0.3 & 0.1 & 0.1 & 0.4 & 0.2 & 0.1 \\
\hline Temperature $\left({ }^{\circ} \mathrm{C}\right)$ & 5.1 & 12.3 & 9.5 & 3.3 & 5.2 & 15.2 & 9.4 & 4.9 \\
\hline Salinity (PSU) & 0.5 & 0.6 & 0.5 & 0.0 & 0.3 & 0.5 & 0.5 & 0.1 \\
\hline
\end{tabular}




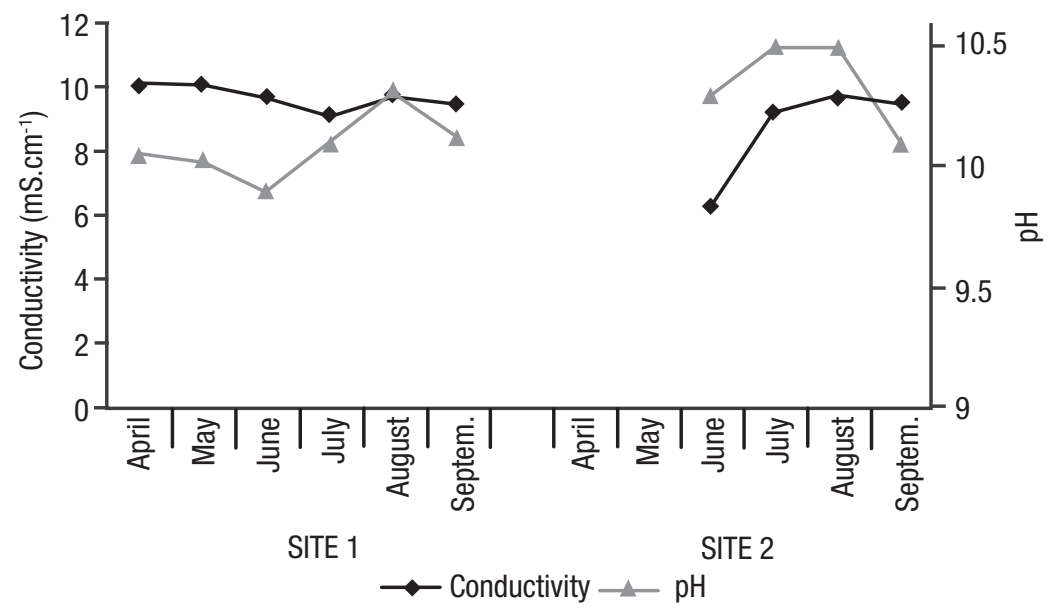

Figure 2. Changes in the conductivity and pH over the study period (2012) at sites 1 and 2 at the Sauce Grande site (Argentine Pampean wetland).

Phytoplankton quantitative analysis. The ANOVA performed on phytoplankton abundance did not detect differences between sampled sites $(F=0.005, p>0.05)$. However, significant differences between months $(\mathrm{F}=6.36, p<0.05)$ were found. A cluster analysis to group months regarding abundance (Fig. 4) was also performed. April and September, July and May, and June and August were grouped for this analysis.

At site 1 , total abundance showed values of $3.6 \times 10^{6} \mathrm{ind}^{-\mathrm{ml}^{-1}}$ in September and $5.4 \times 10^{6}$ ind. $\mathrm{ml}^{-1}$ in July 2012 (Fig. 5). At site 2, abundance ranged from $4.0 \times 10^{6}$ to $5.1 \times 10^{6} \mathrm{ind}^{\mathrm{ml}} \mathrm{m}^{-1}$ in April and May 2012, respectively. The total average phytoplankton abundance was $4.4 \times 10^{6}$ ind. $\mathrm{ml}^{-1}$ at both sites, and Cyanobacteria were the most abundant group, followed by Chlorophyta and Bacillariophyta (Fig. 5). Synechocystis salina Wislouch was the dominant species throughout the entire period, reaching a relative representation of $47 \%$ of the total abundance in September at site 1 and $45 \%$ in August at site 2. Chroococcus minimus (Keissler) Lemmermann, Aphanocapsa elachista W. West et G.S. West and A. nubilum Komárek et Kling were the species with the second highest abundance at both sites.
Cluster Analysis The cluster analysis performed on the physicochemical variables (conductivity, temperature, depth, $\mathrm{pH}$, salinity, and turbidity) appears in the figure 6 . Three groups were established: 1) a "cold" group (S1 May, June, and July), in which the temperature did not exceed $8^{\circ} \mathrm{C}$ and the conductivity and depth averaged $9.5 \mathrm{mS} \mathrm{cm}^{-1}$ and $0.27 \mathrm{~m}$, respectively; 2) a "warm" group (S1 April, S1 August, and S1 and S2 September), with the temperature above $12{ }^{\circ} \mathrm{C}$ and conductivity greater than $9.5 \mathrm{mS} \mathrm{cm}^{-1}$, and 3) a "alkaline" group (S2 July and August) with high pH records (10.5). The lowest conductivity value of $6.27 \mathrm{mS}^{-\mathrm{cm}^{-1}}$ caused the sample S2 June to be separated from the other groups.

Principal Component Analyses (PCA). The PCA-1 included the abundance of the represented taxonomic groups (Cyanobacteria, Chlorophyta, and Bacillariophyta) during the entire study period in conjunction with the physicochemical variables for each sampling site shown in Figure 7. The turbidity was included in the analysis, but did not show correlation with any axis, so the variable was removed from the graphic result. For S1, the first two ordination axes explain $85.5 \%$ of the total variance (Fig. $7 \mathrm{~A}$ ), the positive portion of the first axis represents the conductivity, salinity, and abundance of Bacillariophyta, and the negative portion relates to the $\mathrm{pH}$

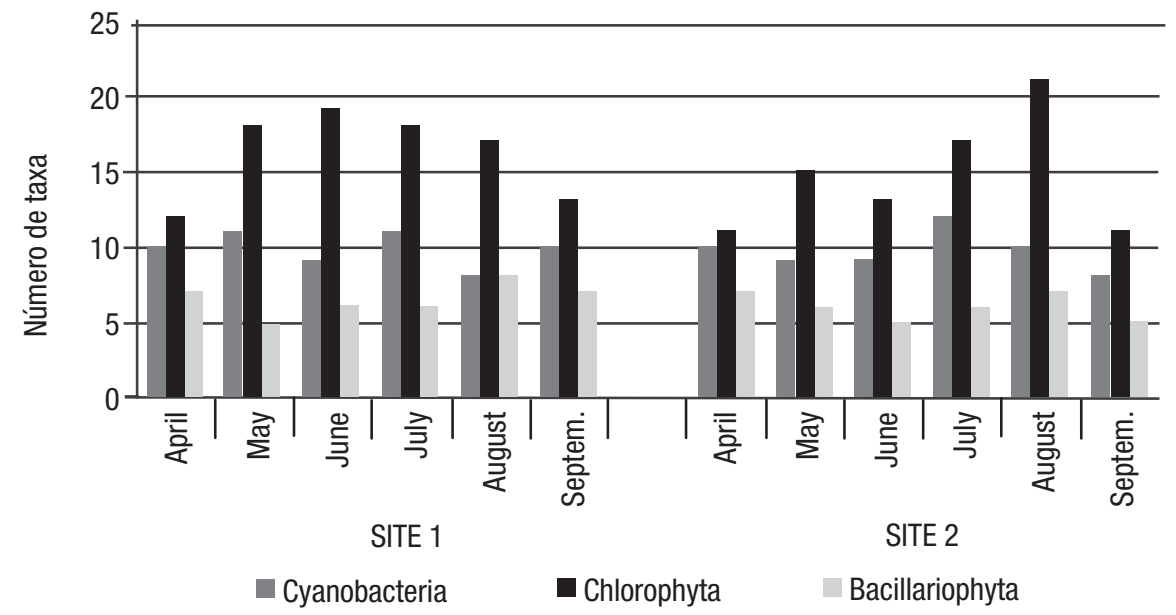

Figure 3. Number of phytoplankton taxa of the three principal groups found during the study period at the Sauce Grande site (Argentine Pampean wetland). 
Table 2. List of the phytoplankton taxa recorded in the Sauce Grande shallow lake, in an Argentine Pampean wetland, during April-September 2012 for site 1 and site 2. Differential species at each site are highlighted in gray. Only the keys of the taxa with $\geq 70 \%$ frequency of occurrence are presented, as selected for the PCA-2.

\begin{tabular}{|c|c|c|c|}
\hline Key & Taxa & Site 1 & Site 2 \\
\hline & Chlorophyta & & \\
\hline & Ankistrodesmus falcatus Corda & $x$ & $x$ \\
\hline & Crucigenia quadrata Morren & $x$ & $\mathrm{x}$ \\
\hline & Dictyosphaerium ehrembergianum Näegeli & $x$ & $x$ \\
\hline & Dictyosphaerium pulchellum var minutum Deflandre & $x$ & $x$ \\
\hline & Eutetramorus cf. fotii (Hindák) Komárek & $x$ & $x$ \\
\hline \multirow[t]{3}{*}{ Jurja } & Juranyiella javorkae (Hortobágyi) Hortobágyi & $x$ & $x$ \\
\hline & Kirchneriella cf. microscopica Nygard & $x$ & $x$ \\
\hline & Lagerheimia subsalsa Lemmermann & $x$ & $x$ \\
\hline \multirow[t]{13}{*}{ Monco } & Monoraphidium contortum (Thuret) Komárková-Legnerová & $x$ & $x$ \\
\hline & M. minutum (Nägeli) Komárková-Legnerová & $x$ & $x$ \\
\hline & M. tortile (West et G.S.West) Komárková-Legnerová & $x$ & $x$ \\
\hline & Oocystella borgei (J.Snow) Hindák & & $\mathrm{x}$ \\
\hline & O. marsonii (J.Snow) Hindák & $x$ & $x$ \\
\hline & Oocystis borgei J.Snow & $x$ & $\mathrm{x}$ \\
\hline & 0. eremosphaeria G.M. Smith & & $x$ \\
\hline & Pediastrum boryanum (Turp.) Meneghini & & $\mathrm{x}$ \\
\hline & P. duplex Meyen & $X$ & $\mathrm{x}$ \\
\hline & Planctonema lauterbornii Schmidle & $x$ & $x$ \\
\hline & Quadricoccus ellipticus Hortobágyi & $x$ & $x$ \\
\hline & Scenedesmus costato-granulatus Skuja & $x$ & $x$ \\
\hline & S. intermedius Chodat & $x$ & $x$ \\
\hline \multirow[t]{7}{*}{ Scena } & S. nanus Chodat & $x$ & $x$ \\
\hline & S. quadricauda (Turp.) de Brebisson & $x$ & $x$ \\
\hline & S. cf. subspicatus Chodat & $x$ & $x$ \\
\hline & Schoederia setigera (Schröder) Lemmermann & $x$ & $x$ \\
\hline & Staurastrum planctonicum (Teiling) & $x$ & \\
\hline & Tetraedron caudatum (Corda) Hansgirg & $x$ & \\
\hline & T. minimun (A. Braun) Hansgirg & $x$ & \\
\hline Tetrae & T. muticum (A. Braun) Hansgirg & $x$ & $\mathrm{x}$ \\
\hline \multirow[t]{2}{*}{ Tetras } & $\begin{array}{l}\text { Tetrastrum staurogenieforme (Schröder) Lemmermann } \\
\text { Cyanobacteria }\end{array}$ & $\mathrm{X}$ & $\mathrm{x}$ \\
\hline & Aphanocapsa conferta (West et G.S.West) Komárková-Legnerová et Cronberg & $x$ & $x$ \\
\hline Aphel & A. elachista W.West et G.S.West & $x$ & $x$ \\
\hline \multirow[t]{8}{*}{ Aphhol } & A. holsática (Lemmermann) Cronberg et Komárek & $x$ & $x$ \\
\hline & A. incerta (Lemmermann) Cronberg et Komárek & $x$ & $x$ \\
\hline & A. nubilum Komárek et Kling & $x$ & $\mathrm{x}$ \\
\hline & Aphanotece clathrata (West et G.S.West) & $x$ & \\
\hline & A. cf. saxicola Nägeli & $\mathrm{X}$ & $\mathrm{x}$ \\
\hline & Chroococcus minimus (Keissler) Lemmermann & $\mathrm{x}$ & $\mathrm{x}$ \\
\hline & C. vacuolatus Skuja & $x$ & $\mathrm{x}$ \\
\hline & Cyanodictyon planctonicum Meyer & $x$ & $x$ \\
\hline \multirow[t]{2}{*}{ Merte } & Merismopedia tenuissima Lemmermann & $x$ & $x$ \\
\hline & Microcystis wesenbergii (Komárek) Komárek & $x$ & \\
\hline \multirow[t]{3}{*}{ Synsa } & Synechocystis salina Wislouch & $x$ & $\mathrm{x}$ \\
\hline & Synechococcus nidulans (Pringsheim) Komárek & & $\mathrm{x}$ \\
\hline & Bacillariophyta & & \\
\hline \multirow[t]{3}{*}{ Aulgr } & Aulacoseira granulata (Ehrenberg) Simonsen & $x$ & $x$ \\
\hline & Chaetoceros muelleri Lemmermann & & $x$ \\
\hline & Cyclotella meneghiniana Kützing & $x$ & $\mathrm{x}$ \\
\hline \multirow[t]{7}{*}{ Hyppo } & Hippodonta sp. & $x$ & $x$ \\
\hline & Navicula aff. gregaria Donkin & $x$ & \\
\hline & Pinnularia sp. & $x$ & $x$ \\
\hline & Pseudostaurosira brevistriata var. inflata (Pantocsek) Hartley & $x$ & $x$ \\
\hline & Pseudostaurosira sp. 1 & $x$ & $x$ \\
\hline & Pseudostaurosira sp. 2 & $x$ & $x$ \\
\hline & Surirella striatula Turpin & $X$ & $x$ \\
\hline
\end{tabular}




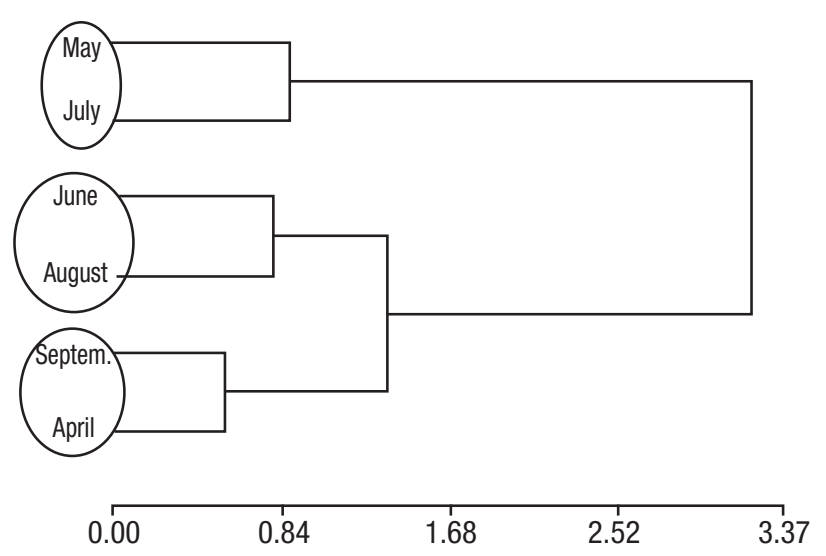

Figure 4. Cluster grouping of monthly samples according to phytoplankton abundance. Complete linkage. Distance: Euclidea.

and the abundance of Cyanobacteria. The second axis is related to the temperature, the depth (positive portion), and the abundance of Chlorophyta (negative portion). April was characterized by the highest salinity and conductivity and less phytoplankton abundance, especially of Cyanobacteria, whereas samples from May and June showed a high density of Chlorophyta and Bacillariophyta individuals, as well as lower $\mathrm{pH}$ and depth records. July had the highest phytoplankton abundance, in particular Cyanobacteria, and the lowest temperature and depth records. During August and September the highest $\mathrm{pH}$ and depth records and the lowest phytoplankton abundance of Chlorophyta and diatom representatives occurred (Fig. 7A). For site 2 (Fig. 7B), the first two ordination axes explained $82.9 \%$, the positive portion of the first axis represents the abundance of Bacillariophyta and Chlorophyta, and the negative portion relates to the abundance of Cyanobacteria, temperature, conductivity, and salinity. The second axis is related to the $\mathrm{pH}$ (positive portion) and depth (negative portion). June showed the highest abundance of Chlorophyta and BaciIlariophyta. July and August showed high pH, salinity, conductivity, and a significant abundance of Cyanobacteria. September had high temperature and depth records and lower abundances of green algae and diatoms (Fig. 7B).

The PCA-2 was based on the specific abundance of selected species with the $\mathrm{F} 0 \geq 70 \%$ parameter that explained $71.2 \%$ of the total variance (Fig. 8). This analysis allowed us to establish a monthly ordination of samples without finding any differences between sampling sites. In this regard, April samples were related to a high abundance of Scenedesmus nanus Chodat; May and June showed high abundance of Juranyiella javorkae (Hortobágyi) Hortobágyi and Tetraedron muticum (A. Braun) Hansgirg (Chlorophyta), Aulacoseira granulata (Ehrenberg) Simonsen, and Hyppodonta sp. (Bacillariophyta). July showed the highest abundance of Monoraphidium contortum (Thuret) KomárkováLegnerová, Tetrastrum staurogenieforme (Schröder) Lemmermann (Chlorophyta), and A. elachista (Cyanobacteria). The samples of August and September were characterized by a low abundance of selected species and a high abundance of the dominant species $S$. salina and Aphanocapsa holsatica (Lemmermann) Cronberg et Komárek.

Spearman Correlations. The different taxonomic groups showed significant correlations $(p<0.05)$ with the different water physicochemical and environmental variables recorded (Table 3). The exception was turbidity, which showed no correlation with any taxonomic group. Cyanobacteria exhibited a positive correlation with conductivity at site 1 (R-Spearman $=0.77$ ), whereas Chlorophyta and Bacillariophyta were negatively correlated with conductivity (R-Spearman $=-0.80$ for both), temperature (R-Spearman $=-0.80$ for both), and salinity (R-Spearman $=-0.74$ and -0.95 , respectively). Diatoms showed a positive correlation with conductivity and a negative correlation with $\mathrm{pH}$ (R-Spearman = 0.83 and -0.77 respectively) at site 1 .

\section{DISCUSSION}

The water level of the Sauce Grande shallow lake during our study period was significantly lower than the decrease that occurred during fall 2010 (Ferrer et al., 2012). It is known that this water body is highly dependent on in situ rainfall (Fornerón et al., 2010b) and the severe drought recorded in the area may be related to the ongoing global warming tendency (see Resolution331/2010 of the Agriculture, Livestock, and Fisheries Ministry of Buenos Aires Province, http://www.minagri. gob.ar). Moreover, the man-made water deviation from the tributary river to adjacent fields worsened the situation (see data provided by the Water Authority, Infrastructure Ministry, Buenos Aires Province, http:// www.ada.gba.gov.ar).

The decrease in the water level was accompanied by an increase in turbidity, with saturation values throughout the study period. According to Cony et al. (2014) who studied the nature of the suspended organic matter in the lake, the phytoplankton community was mainly responsible for the turbidity, although no clear correlation between phyto-

Table 3. Correlation coefficients between physicochemical variables and abundance of taxonomic groups of phytoplankton in an Argentine Pampean wetland (bold values are significant at $p<0.05$ ).

\begin{tabular}{|c|c|c|c|c|c|c|}
\hline \multirow[b]{2}{*}{ Variable } & \multicolumn{3}{|c|}{ Site 1} & \multicolumn{3}{|c|}{ Site 2} \\
\hline & Cyanobacteria & Chlorophyta & Bacillariophyta & Cyanobacteria & Chlorophyta & Bacillariophyta \\
\hline $\mathrm{pH}$ & 0.66 & -0.66 & -0.77 & 0.21 & 0.11 & 0.32 \\
\hline Conductivity $\left(\mathrm{mS} . \mathrm{cm}^{-1}\right)$ & 0.77 & 0.37 & 0.83 & 0.20 & -0.80 & -0.80 \\
\hline Temperature $\left({ }^{\circ} \mathrm{C}\right)$ & -0.49 & -0.66 & -0.09 & -0.20 & -0.80 & -0.80 \\
\hline Salinity (PSU) & -0.67 & 0.00 & 0.58 & 0.32 & -0.74 & -0.95 \\
\hline Depth (m) & 0.09 & -0.60 & -0.37 & 0.60 & 0.40 & -0.40 \\
\hline
\end{tabular}




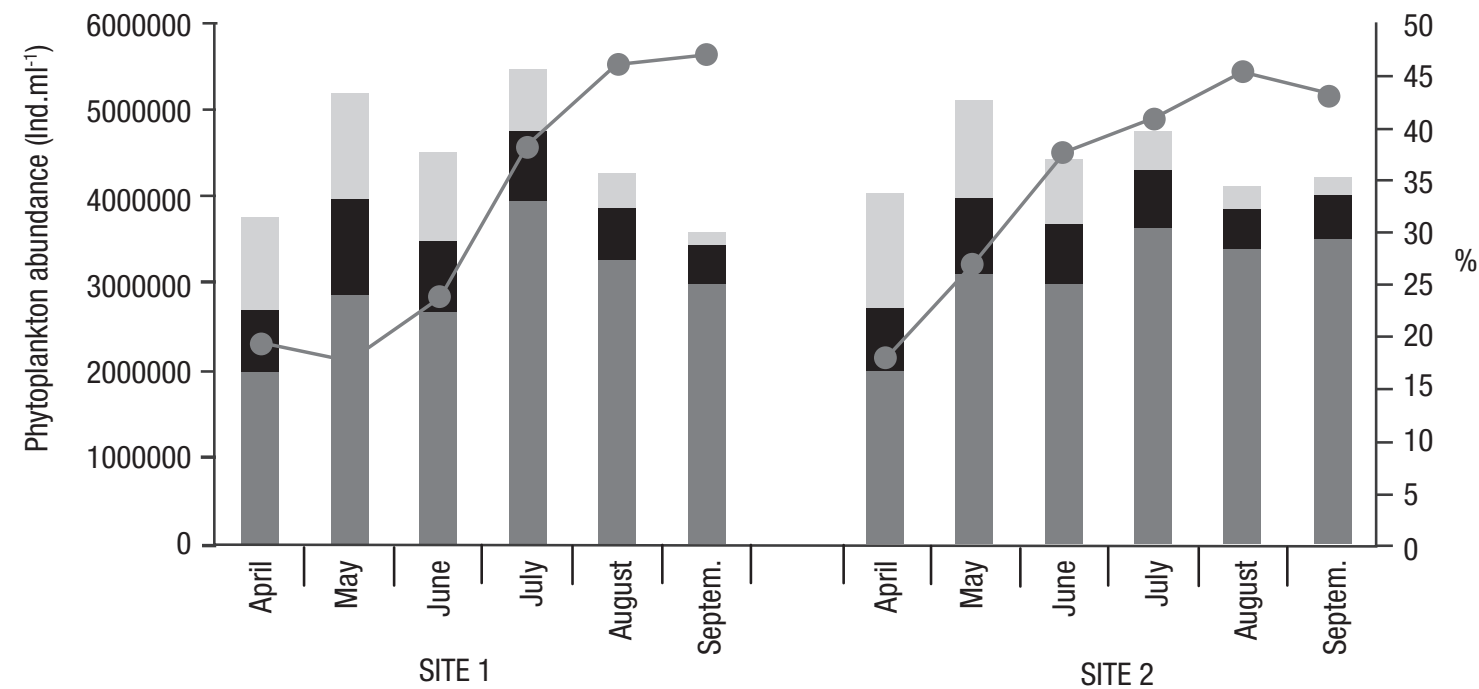

$$
\text { Bacillariophyta Chlorophyta Cyanobacteria }
$$

SITE 2

Figure 5. Monthly variation of the abundance of the phytoplankton taxonomic groups and the percentage of the dominant species (Synechocystis salina) during the study period at both Sauce Grande study sites (Argentine Pampean wetland).

plankton abundance and turbidity was found. The increase in turbidity was also derived from the concurrent effect of sediment removal by wind and the shallow depth, also mentioned by other authors for these environments (James et al., 2004; Quirós et al., 2005, Lagomarsino et al., 2015). Our results made it clear that there was no evident action by any of the other physicochemical variables studied.

Nevertheless, the total phytoplankton density values recorded of $10^{6}$ ind. $\mathrm{ml}^{-1}$ during the study period, exceeded the values by an order of $10^{3}$ ind. $\mathrm{ml}^{-1}$ with respect to those recorded in autumn 2010 (Ferrer et al., 2012). In particular, Cyanobacteria densities exceeded the $1.10^{4}$ cells. $\mathrm{ml}^{-1}$, densities that, according to Pizzolon (1996), can be considered a cyanobacterial bloom. In particular, O'Farrell et al. (2015) highlight the role of changes in water level in the Pampean wetlands in altering phytoplankton abundance and especially in establishing cyanobacterial blooms. Moreover, these authors also mention that the sequence of nutrient mobilization from land to the receiving waters after intense rainfall and flushing subsidence followed by protracted periods of drought could explain the massive cyanobacterial blooms in estuaries, reservoirs, and lakes (0'Farrell et al., 2015). Previous research has shown that the underwater light climate could strongly affect the phytoplankton structure and primary production in the lakes of this region (Allende et al., 2009). Light-limiting conditions prevail in the turbid Pampean lakes (Llames et al., 2009), and it is known that light availability affects algal competition (Reynolds, 2006) and phytoplankton diversity (Reynolds, 1998; Stomp et al., 2004). Reynolds (1994) noted that large amounts of suspended material have a profound effect on the attenuation of underwater light, with subsequent selection of "light antenna," which favors species that have a large surface/volume ratio (SA/V). Small chroococcalean Cyanobacteria species are clearly well adapted to these conditions due to their high SA/V (Izaguirre et al., 2015). In this study, the dominant species was precisely Synechocystis salina and the subdominant ones were Chroococcus minimus, Aphanocapsa elachista, and A. nubilum.

Cony et al. (2014) recently described the Sauce Grande shallow lake as hypereutrophic due to the high levels of chlorophyll, the high $\mathrm{pH}$ records, and the stability in the water column. In addition, the salinity recorded was higher in 2012 than in 2010 (Ferrer et al., 2012), as a result of the prolonged hydraulic residence times caused by the drought (see Beklioglu et al., 2007 and Beklioglu et al., 2011), a situation that also favors incipient cyanobacterial blooms (see Sellner et al., 1988).

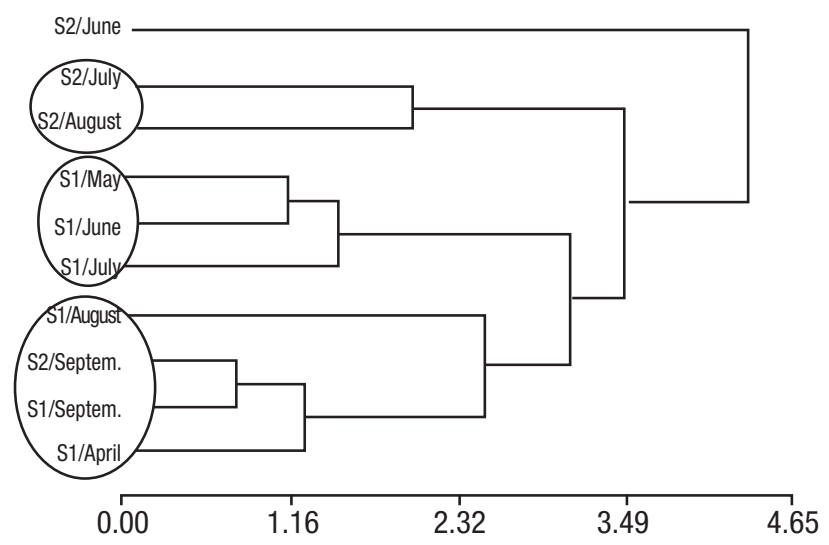

Figure 6. Cluster grouping of sampling stations according to the physicochemical variables. Complete linkage. Distance: Euclidea. 
a)

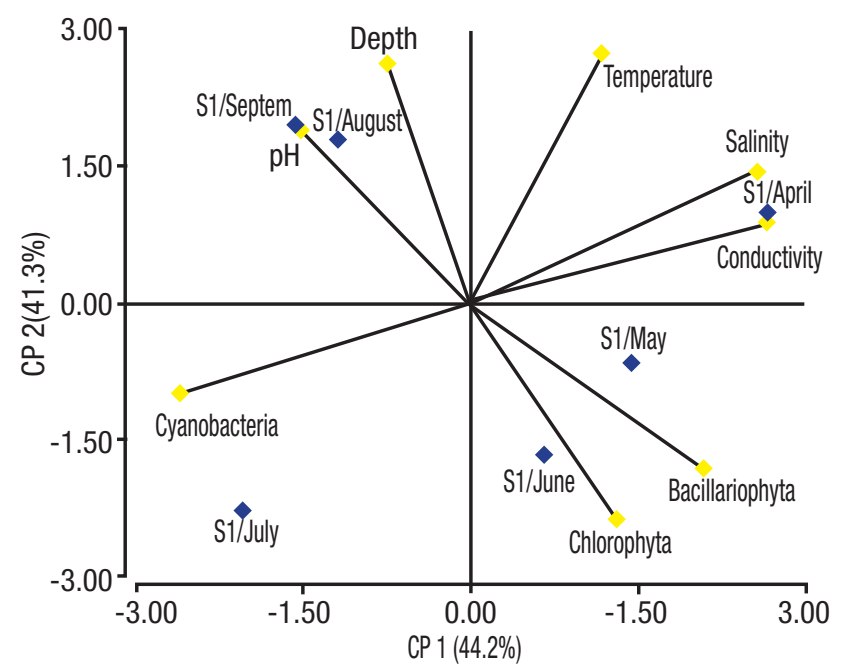

b)

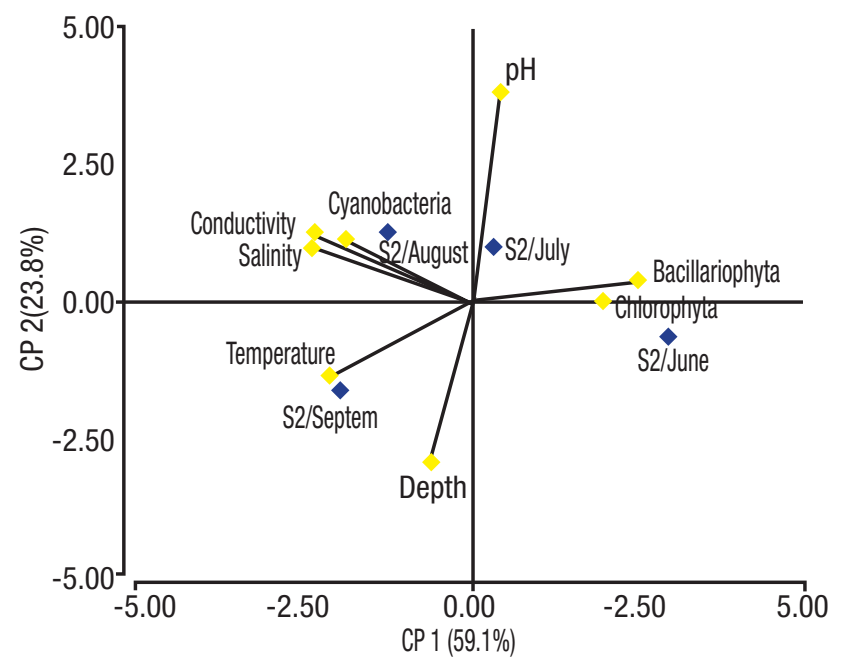

Figures 7a-b. PCA-1. Biplot of samples and abundance of taxonomic groups, in the plane of the first two principal components, for Site 1 (a) and Site 2 (b) at Sauce Grande (Argentine Pampean wetland).

All these factors could explain the abundance of cyanobacteria in general and the dominant species in particular. Several authors (Havens et al., 1998; Huisman \& Hulot 2005; Havens, 2008) have mentioned that (1) high concentrations of nutrients, (2) high water temperature, (3) high $\mathrm{pH}$ values, (4) low N:P, and (5) stability of the water column are causative factors involved in the development of cyanobacterial blooms.

Qualitatively, the phytoplankton community was not very different from that of autumn 2010, when Chlorophyta also had the highest number of recorded taxa, followed by Cyanobacteria and Bacillariophyta, although the green algae Planctonema lauterbornii Schmidle showed seasonal dominance in that period (Ferrer et al., 2012).

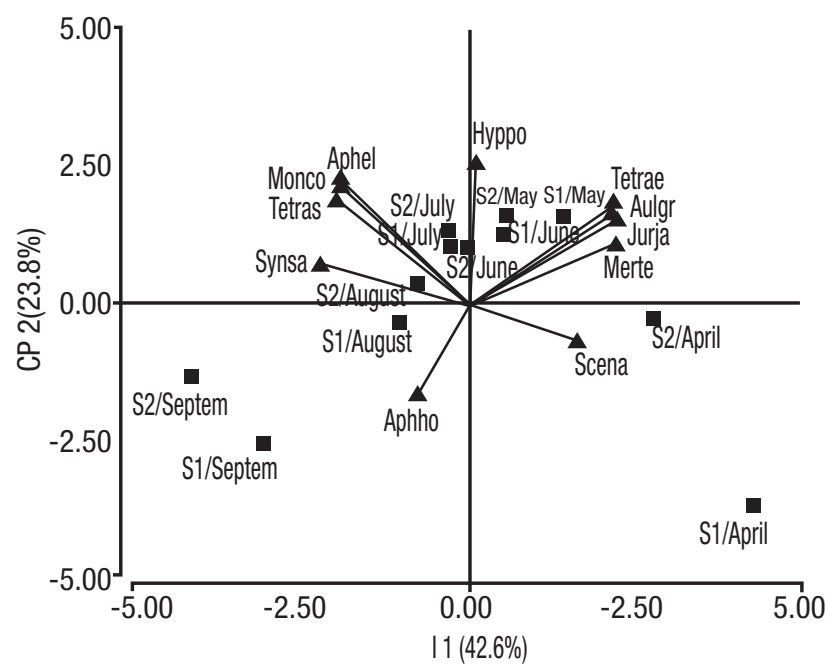

Figure 8. PCA-2. Biplot of samples and species selected in the plane of the first two principal components, depending on specific species abundance. For the species key, see Table 2.
The multivariate analysis showed that certain water environmental factors, i.e. temperature, conductivity, salinity, and $\mathrm{pH}$ determine the dynamics of phytoplankton, leading to a seasonal succession of species in the community, with a clear dominance of Cyanobacteria. Cluster analysis showed that clustered samples were based on temperature, depth, conductivity, $\mathrm{pH}$, and turbidity, and we were able to identify low temperature (S1 May to July), high temperature (S1 April, S1 August, and S1, S2 September), and alkaline pH (S2 July and August) groups. Furthermore, the PCA-1 A and B showed the spatial homogeneity of the water body based on similarities in the biological parameters tested at the two sampling sites. We considered that the predominant physicochemical variable was depth. Here, the largest difference between sites is observed in the August sample, in which the minimum was recorded at S2 $(0.13 \mathrm{~m})$. The PCA-2 demonstrated the existence of a monthly separation of samples based on the total abundance of taxonomic groups and the abundance of selected species, respectively. We can attribute the latter to the increasing dominance of $S$. salina, which generates a decline in species diversity and the level of representation of the taxonomic groups.

The chlorophycean species Juranyella javorkae, Monoraphidium contortum, Tetraedron muticum, Tetrastrum staurogenieforme, the cyanobacteria Aphanocapsa elachista, and the diatoms Aulacoseira granulata and Hyppodonta sp. appeared in May, June and July (Cluster Group "cold" PCA-2, Fig. 8). Given these results, Izaguirre et al. (2015) and Fernández et al. (2014) confirmed the dominance of small Chlorococcales, colonial Cyanobacteria, and the diatom A. granulata for the same period, but in other shallow eutrophic environments of the region. The samples of August and September were characterized by the elevated dominance of Cyanobacteria and in particular S. salina, associated with the highest temperature recorded, also reported by Fernández et al. (2009) for the Paso de las Piedras reservoir nearby.

The different taxonomic groups represented in the Sauce Grande shallow lake showed significant correlations with different physicoche- 
mical variables recorded in the water body (Table 3). Cyanobacteria showed a positive correlation with conductivity, which increased in August and September when this taxonomic group recorded its highest abundance (Cluster Group "warm" Fig. 6; PCA-1, Fig. 7). Further, Chlorophyta and Bacillariophyta showed negative relations with conductivity, salinity, and temperature (Cluster Group "cold" Fig. 6; PCA-1, Fig. 7).

In conclusion, the results obtained in this study demonstrate the high susceptibility of the phytoplankton community of the Sauce Grande shallow lake to changes in the water environment and physicochemical variables, principally to the fluctuations in the water level, conductivity, salinity, and pH. In particular, Chlorophyta and Bacillariophyta are sensitive to high values of salinity and conductivity, while in these conditions small species of Cyanobacteria dominate the phytoplankton community. In addition, the results showed the existence of a monthly, nonspatial, separation, with samples as a function of the total abundance of taxonomic groups and the abundance of the species selected. In other words, there is homogeneity between sites on phytoplankton abundance, both as groups and as species, while between months there are differences in this respect. We could attribute this to the growing dominance of $S$. salina, which increases gradually from April to September 2012 in both sites and causes the diversity of species and the level of representation of taxonomic groups to decrease.

\section{ACKNOWLEDGMENTS}

This research was carried out with the support of a grant from the Secretaría General de Ciencia y Tecnología, Universidad Nacional del Sur, Argentina, PGI 24/B196. NLC is a fellow of the CIC (Comisión de Investigaciones Científicas de la Provincia de Buenos Aires, Argentina). EJC is an honorary research member of the CIC. The authors thank Lic. Ricardo Camina for his statistical advice.

\section{REFERENCES}

Agriculture, Livestock and Fisheries Ministry of Buenos Aires Province. 2010. Resolution331/2010. Available online at http://www.minagri.gob.ar (downloaded may 25, 2012).

Allende, L., G. Tell, H. Zagarese, A. Torremorell, G. Pérez, J. Bustingorry, R. Escaray \& I. Izaguirre. 2009. Phytoplankton and primary production in clear-vegetated, inorganic-turbid, and algal-turbid shallow lakes from the pampa plain (Argentina). Hydrobiologia 624: 45-60. D0I: 10.1007/s10750-008-9665-9.

Bekloglu, M., S. Romo, I. Kagalou, X. Quintana \& E. Becares. 2007. State of the art in the functioning of shallow Mediterranean lakes: workshop conclusions. Hydrobiologia 584: 317-326. D0I: 10.1007/s10750007-0577-x.

Bekloglu, M., M. Meerhoff, M. Søndergaard \& E. Jeppesen. 2011. Eutrophication and restoration of shallow lakes from a cold temperate to a warm Mediterranean and a (sub) tropical climate. In: Ansari, A., A. S. Singh Gill, G. R. Lanza \& W. Rast (Eds.). Eutrophication: Causes, consequences and control. Netherlands, Springer, pp. 91-108. D0I: 10.1007/978-94-007-7814-6.

Bilotta, G. S. \& R. E. Brazier. 2008. Understanding the influence of suspended solids on water quality and aquatic biota. Water Re- search 42 (12): 2849-2861. D0l: http://dx.doi.org/10.1016/j. watres.2008.03.018.

Bourrely, P. 1966. Les alguesd'eaudouce.Initiation a la systematique. Tome 1. Les algues vertes. Boubée Saint-André-des Arts, Paris.

Calıuri, M. C., A. C. A. Dos Santos \& S. Jati. 2002. Temporal changes in the phytoplankton community structure in a tropical and eutrophic reservoir (Barra Bonita, S.P. Brazil). Journal of Plankton Research 24 (7): 617-634. DOI: https://doi.org/10.1093/plankt/24.7.617.

Cony, N. L., N. C. Ferrer \& E. J. CÁCeres. 2014. Evolución del estado trófico y estructura del fitoplancton de un lago somero de la región pampeana: laguna Sauce Grande (Pcia. de Buenos Aires, Argentina). Biología Acuática 30: 79-91.

Coops, H., M. Bekloglu \& T. L. Crisman. 2003. The role of water-level fluctuations in shallow lake ecosystems: work shop conclusions. Hydrobiologia 506: 23-27.

Downing, J. A., Y. T. Prairie, J. J. Cole, C. M. Duarte, L. J. Tranvik, R. G. Striegl, W. H. McDowell, P. Kortelainen, N. F. Caraco, J. M. Melack \& J. J. MiddelbuRG. 2006. The global abundance and size distribution of lakes, ponds, and impoundments. Limnology and Oceanography 51 (5): 2388-2397.

Fernández, C., E. R. Parodi \& E. J. Cáceres. 2009. Limnological characteristics and trophic state of Paso de las Piedras Reservoir: an inland reservoir in Argentina. Lakes and Reservoirs: Research and Management 14: 85-101. DOI: 10.1111/j.1440-1770.2009.00393.x.

Fernández, C., E. J. Cáceres \& E. R. Parodi. 2014. Phytoplankton Development in a Highly Eutrophic man-made Lake from the Pampa plain of Argentina-a functional Approach. International Journal of Environmental Research 8 (1): 1-14.

Ferrer, N. C., N. L. Cony, C. F. Fornerón \& M. C. Piccolo. 2012. Caracterización del fitoplancton y estado trófico de la laguna Sauce Grande (Provincia de Buenos Aires, Argentina) en el otoño de 2010. Biología Acuática 27: 129-141.

Fornerón, C. F., M. C. Piccolo \& M. E. Carbone. 2010a. Análisis de la laguna Sauce Grande (Argentina). Huellas 14: 11-30.

Fornerón, C. F., M. C. Piccolo, N. L. Cony \& N. C. Ferrer. 2010b. Hidrografía de la Laguna Sauce Grande durante el otoño de 2010 (Provincia de Buenos Aires). Contribuciones Científicas Sociedad Argentina de Estudios Geográficos-GAEA 22: 197-206.

Guarrera, S. A., S. Cabrera, E. López \& G. Tell. 1968. Fitoplancton de las aguas superficiales de la Provincia de Buenos Aires. I. Área de la Pampa Deprimida. Revista del Museo de La Plata 10 (49): 223-331.

Guarrera, S. A., L. Malacalza \& F. P. López. 1972. Fitoplancton de las aguas superficiales de la Provincia de Buenos Aires. Revista del Museo de La Plata 67: 161-222.

Havens, K. E., E. J. Phlips, M. F. CICHRA \& B. LI. 1998. Light availability as a possible regulator of cyanobacteria species composition in a shallow subtropical lake. Freshwater Biology 39: 547-556.

Havens, K. E. 2008. Cyanobacteria blooms: effects on aquatic ecosystems. In: Hudnell, H. K. (Ed.). Cyanobacterial harmful algal blooms: advances in experimental medicine and biology. New York Springer Science, pp. 733-748. 
HINDÁK, F. 1977. Studies on the chlorococcal algae (Chlorophyceae). I. Publishing House of the Slovak Academy of Sciences, Bratislava.

HINDÁk, F. 1984. Studies on the chlorococcal algae (Chlorophyceae). III. Publishing House of the Slovak Academy of Sciences, Bratislava.

HIndÁk, F. 1988. Studies on the chlorococcal algae (Chlorophyceae) IV. Publishing House of the Slovak Academy of Sciences, Bratislava.

HIndÁk, F. 1990. Studies on the chlorococcal algae (Chlorophyceae) V. Publishing House of the Slovak Academy of Sciences, Bratislava.

Huisman, J. \& F. D. Hulot. 2005. Population dynamics of harmful cyanobacteria. Factors affecting species composition. In: Huisman, J., H. C. P. Matthijs \& P. M. Visser (Eds.). Harmful cyanobacteria. Netherlands Springer, pp. 143-176.

Izaguirre, I., M. L. Sánchez, M. R. Schiaffino, I. O'Farrell, P. Huber, N. Ferrer, J. Zunino, L. Lagomarsino \& M. Mancini. 2015. Which environmental factors trigger the dominance of phytoplankton species across a moisture gradient of shallow lakes? Hydrobiologia 752 (1): 47-64. DOI: 10.1007/s10750-014-2007-1.

Jeppesen, E., B. Kronvang, M. Meerhoff, M. Søndergaard, K. M. Hansen, H. E. Andersen, T. L. Lauridsen, M. Beklioglu, A. Özen \& J. E. Olesen. 2009. Climate change effects on runoff, catchment phosphorus loading and lake ecological state, and potential adaptations. Journal Environmental Quality 38 (5): 1930-1941. DOI: 10.2134/jeq2008.0113.

Jeppesen, E., S. Brucet, L. Naselli-Flores, E. Papastergiadou, K. Stefanidis, T. Nõges, P. Nõges, J. L. Attayde, T. Zohary, J. Coppens, T. Bucak, R. Fernandes Menezes, F. R. Sousa Freitas, M. Kernan, M. Søndergaard \& M. BEKLIOGLU. 2015. Ecological impacts of global warming and water abstraction on lakes and reservoirs due to changes in water level and related changes in salinity. Hydrobiologia 750: 201-227. D0I: $10.1007 / \mathrm{s} 10750-014-2169-\mathrm{x}$.

Komárek, J. \& K. Anagnostidis. 1999. Cyanoprokaryota. 1. Teil: Chroococcales, vol 1. Süsswasserflora von Mitteleuropa. Stuttgart: Fischer Verlag.

KomÁrek, J. \& K. AnAgnostidIs. 2005. Cyanoprokaryota. 2. Teil: Oscillatoriales, vol 2. . Süsswasserflora von Mitteleuropa. München: Elsevier $\mathrm{GmbH}$.

Komárek, J. \& B. Fotт. 1983. Chlorophyceae (Grünalgen) Ordnung: Chlorococcales, vol 16. Das Phytoplankton des Süsswasser Systematik und Biologie. Sttugart: E. Schweizerbart'sche Verlagsbuchhandlung.

Llames, M.E., L. Lagomarino, N. Diovisalvi, P. Fermani, A. M. Torremorell, G. Pérez, F. Unrein, J. Bustingorry, R. Escaray, M. Ferraro \& H. Zagarese. 2009. The effects of light availability in shallow, turbid waters: a mesocosm study. Journal of Plankton Research 31: 1517-1529. DOI: https://doi.org/10.1093/plankt/fbp086

McAlice, B. J. 1971. Obsevations on the small-scale distributions of estuarine phytoplankton. Marine Biology 7: 100-111.

Moss, B., S. Kosten, M. Meerhoff, R. W. Battarbee, E. Jeppesen, N. Mazzeo, K. Havens, G. Lacerot, Z. Liu, L. De Meester, H. Paerl \& M. Scheffer. 2011. Allied attack: climate change and eutrophication. Inland Waters 1 : 101-105. D0I: 10.5268/IW-1.2.359.
PhLIPS, E. J., S. BADYLAK \& T. Grosskopf. 2002. Factors affecting the abundance of phytoplankton in a restricted subtropical lagoon, the Indian River Lagoon, Florida, USA. Estuarine, Coastal and Shelf Science 55 (3): 385-402. Also available at: http://www.idealibrary.com. DOI: 10.1006/ecss.2001.0912.

Pizzolon, L. 1996. Importancia de las cianobacterias como factor de toxicidad en las aguas continentales. Interciencia 21 (6): 239-245. También disponible en la página web http://www.interciencia.org. ve.

Quirós, R., A. M. Rennella, M. B. Boveri, J. J. Rosso \& A. Sosnovsky. 2002a. Factores que afectan la estructura y el funcionamiento de las lagunas pampeanas. Ecología Austral 12: 175-185.

Quirós, R., J. J. Rosso, A. M. Rennella, A. Sosnovsky \& M. B. Boveri. 2002b. Análisis del estado trófico de las lagunas pampeanas (Argentina). Interciencia 27 (11): 584-591.

Quirós, R. 2005. La ecología de las lagunas de las Pampas. Investigación y Ciencia 1: 1-13.

ReYnoLds, C. S. 1998. What factors influence the species composition of phytoplankton in lakes of different trophic status. Hydrobiologia 369 (370): 11-26.

Reynolds, C. S. 2006. The Ecology of Phytoplankton. Cambridge Cambridge University Press.

Ringuelet, R. A. 1972. Ecología y biocenología del hábitat lagunar o lago de tercer orden de la región neotrópica templada (Pampasia Sudoriental de la Argentina). Physis 31 (82): 55-76.

Rojo, C., E. Ortega-Mayagoitia \& M. Álvarez-Cobelas. 2000. Lack of pattern among phytoplankton assemblages. Or, what does the exception to the rule mean?. Hydrobiologia 424: 133-139.

Scheffer, M., S. H. Hosper, M. L. MeiJer, B. Moss \& E. Jeppesen. 1993. Alternative equilibria in Shallow Lakes. Trends in Ecology and Evolution 8 (8): 275-279.

Scheffer, M., S. Szabó, A. Gragnani, E. H. van Ness, S. Rinaldi, N. Kautsky, J. Norberg, R. M. M. Roljackers \& R. J. M. Franken. 2003. Floating plant dominance as a stable state. Proceedings of the National Academy of Sciences 100 (7): 4040-4045. DOI: 10.1073/pnas.0737918100.

Sellner, K. G., R. V. Lacouture \& C. R. Parrish. 1988. Effects of increasing salinity on a cyanobacteria bloom in the Potomac River estuary. Journal of Plankton Research 10: 49-61.

Stomp, M., J. Huisman, F. de Jongh, A. J. Veraart, D. Gerla, M. RiJkeboer, B. W. IBelings, U. I. A. Wollenzien \& L. J. Stal. 2004. Adaptive divergence in pigment composition promotes phytoplankton biodiversity. Nature 432: 104-107. Also available at: www.nature.com/nature.

Torremorell, A., J. Bustingorry, R. Escaray \& H. Zagarese. 2007. Seasonal dynamics of a large, shallow lake, Laguna Chascomús: The role of light limitation and other physical variables. Limnológica 37: 100108. D0l: http://dx.doi.org/10.1016/j.limno.2006.09.002

Water Authority, Infrastructure Ministry Buenos Aires Province. 2013. Available online at http://www.ada.gba.gov.ar (downloaded may 24, 2013). 